\title{
Soil properties and sulfur-oxidizing bacterial diversity in response to different planting patterns of shallot (Allium ascalonicum)
}

\author{
MUHAMMAD JUWANDA ${ }^{1,2, \boldsymbol{v}}$, SAKHIDIN ${ }^{2}$, SAPARSO $^{2}$, KHARISUN $^{2}$ \\ ${ }^{1}$ Faculty of Science and Technology, Universitas Muhadi Setiabudi. Jl. P. Diponegoro Km. 2, Wanasari, Brebes, Central Java, Indonesia. \\ Tel.: +62-283-6199000, Fax.: +62-283-6199001, `email: muhammad.juwanda@gmail.com \\ ${ }^{2}$ Faculty of Agriculture, Universitas Jenderal Soedirman. Jl. Dr. Soeparno No. 61, Purwokerto Utara, Banyumas 53122, Central Java, Indonesia
}

Manuscript received: 18 March 2020. Revision accepted: 29 May 2020.

\begin{abstract}
Juwanda M, Sakhidin, Saparso, Kharisun. 2020. Soil properties and sulfur-oxidizing bacterial diversity in response to different planting patterns of shallot (Allium ascalonicum). Biodiversitas 21: 2832-2839. Sulfur is one of the primary elements required by plants for growth and development. Sulfur-oxidizing bacteria (SOB) can oxidize sulfur to sulfate, which is directly taken up by plant roots. This study aims to evaluate the soil properties and SOB diversity in various shallot planting patterns, i.e. PP1 (shallot-dry seasonshallot-shallot), PP2 (shallot-dry season-shallot-rice), and PP3 (shallot-pulses-shallot-rice). Soil samples were collected from the rhizosphere of the shallot plant and analyzed for the soil properties based on the standard methods. Bacteria isolation was cultured on Starkey broth and Starkey agar. Bacteria isolate was identified based on the 16S rRNA gene sequence and compared to the GenBank database. The results showed that shallot planting patterns influence soil properties and SOB diversity. The highest content of sulfate (41.31 ppm), organic C $(0.957 \%)$, organic matter $(1.650 \%), \mathrm{C} / \mathrm{N}$ ratio $(9.57)$, and SOB diversity was obtained in PP3 planting pattern. Three bacterial strains have been successfully isolated i.e. A-3245D, B-3246F, and C-3247C with their closest related to Burkholderia cepacia, Klebsiella variicola, and Klebsiella aerogenes, respectively. The highest diversity and population density of SOB was in the PP3 planting patterns, i.e Burkholderia cepacia $\left(7.45 \times 10^{5} \mathrm{CFU} / \mathrm{mL}\right)$; Klebsiella variicola $\left(1.79 \times 10^{7} \mathrm{CFU} / \mathrm{mL}\right.$; Klebsiella aerogenes: $\left.3.9 \times 10^{6} \mathrm{CFU} / \mathrm{mL}\right) . K$. variicola can be found in three planting patterns of shallot.
\end{abstract}

Keywords: Bacteria, chemical, shallot, soil, sulfur

\section{INTRODUCTION}

Shallot (Allium ascalonicum L.) is one of the most important vegetables in Indonesia and commonly used as the main ingredient in numerous traditional cuisines (Hilman et al. 2014). The largest shallot-producing regency in the province of Central Java is Brebes which supplies $75 \%$ of the shallots in Central Java and 23\% of the national needs (Hartini 2011). Data from the Central Bureau of Statistics (BPS 2018) showed that shallot yield in Brebes regency decreased from $12.23 \mathrm{t} / \mathrm{ha}$ in 2013 to $10.19 \mathrm{t} / \mathrm{ha}$ in 2017, followed by a decrease in national shallots production. The decline in shallot yield is partially related to the annual water supply. There are three different planting patterns for shallot cultivation by farmers in Brebes, i.e. (i) shallot-dry season-shallot-shallot, (ii) shallot-dry season-shallot-rice and (iii) shallot-pulsesshallot-rice. Due to differences in planting patterns, the use of chemical fertilizers, such as sulfur was varied.

Sulfur is needed by plants in a considerable concentration because sulfur is one of the macro essential nutrients after $\mathrm{N}, \mathrm{P}$, and $\mathrm{K}$ and required for growth and development (Sriramachandrasekharan 2013; Assefa et al. 2015). Methionine and cysteine, the two primary sulfurcontaining amino acids, are both required for protein synthesis. Sufficient level of sulfur in soil is a determinant for the production of shallots and the metabolism of nitrogen in plants (Jaggi and Sharma 2010). Adequate sulfur content in the soil in shallot cultivation results in high yields of bulbs and affects bulb weight per clump, bulb diameter, and bulb yield per hectare (Diriba-Shiferaw et al. 2015; Lasmini et al. 2015). Sulfur level in soil affects soil chemical properties (Losák et al. 2008). The presence of organosulfur corresponds to a distinctive odor of shallot bulbs (Morradi et al. 2013). Since most of the sulfur in soil is present in organic compounds, therefore sulfur can not be absorbed directly by plants (Sridar et al. 2015).

It has been known that sulfur-oxidizing bacteria (SOB) can efficiently convert elemental sulfur and organic carbon of sulfur (unavailable form) into sulfate (available form for the plant) by the sulfur oxidation process (Losák et al. 2008; Fageria 2009; Ullah et al. 2014; Prenafeta-Boldúet al. 2014; Velivelli et al. 2014; Sridar et al. 2015). The oxidation reaction of sulfur to sulfate is as follows (Ryu et al. 2003):

$$
\mathrm{S}^{0}+3 / 2 \mathrm{O}_{2}+\mathrm{H}_{2} \mathrm{O} \longrightarrow 2 \mathrm{H}^{+}+\mathrm{SO}_{4}{ }^{2-}
$$

SOB uses sulfur as a source of energy (Ullah et al. 2014). The presence of SOB in soil results in increased sulfate levels in the soil, consequently increased plant growth. Sulfur level and SOB diversity in soil affect soil chemical properties as well as nutrient availability and $\mathrm{pH}$ (Sabagh et al. 2014). Furthermore, the physical and chemical properties of soil are primarily related to microbial community and activity. The adequate availability of micro-and macronutrients is also important to improve soil fertility, growth, and yield of plants. 
Besides, crop rotation systems by planting different crops can increase yields through improved soil fertility (Riedell et al. 2009; Glab et al. 2013).

Among many bacterial groups, autotrophic and heterotrophic bacteria have been recognized to be involved in the oxidation of sulfur (Hao et al. 2019). Sinha et al. (2008) identified the diversity of SOB especially Klebsiella sp. based on the $16 \mathrm{~S}$ rRNA gene sequence, while Puspitasari et al. (2014) identified the diversity of Bacillus cereus in tin-mining soil. Klebsiella sp. is SOB that can convert sulfur to sulfate (Behera et al. 2016) and can be used as biological fertilizer to increase plant growth because it can provide nutrients needed by plants (Lin et al. 2015; Sulasih and Widawati 2019). Previous studies by Ryu et al. (2003) showed that SOB Acidithiobacillus thiooxidans affects the characteristics of metal content in waste sludge, while SOB Thiobacillus sp. affects the levels of sulfate, phosphate, and $\mathrm{pH}$ in rice fields, rhizosphere of wheat, industrial wastewater and sewage sludge, and enhance sulfur oxidation in soil and increase soil available sulfate (Mohamed et al. 2014; Ullah et al. 2014). A recent study by Pourbabaee et al. (2020) reported that Thiobacillus bacteria in combination with elemental sulfur enhances the oxidation of elemental sulfur resulting in increased nutrient availability in soil, consequently increased plant growth. Therefore, the presence of sulfur oxidizers is crucial to improve sulfur availability to plants at their critical stages to increase crop yields. To date, little is known about soil properties and SOB diversity in the shallot fields. Therefore, this study aimed to determine soil properties and SOB diversity in response to different planting patterns of shallot.

\section{MATERIALS AND METHODS}

\section{Study area}

This study was conducted at the Laboratory of Agrotechnology, Faculty of Agriculture, University of Jenderal Soedirman, Indonesia from April to September 2018. Soil samples were collected from rhizosphere soils from three different sites with ten replications based on planting patterns, namely Planting Pattern 1 (PP1: shallotdry season-shallot-shallot), Planting Pattern 2 (PP2: shallot-dry season-shallot-rice) and Planting Pattern 3 (PP3: shallot-pulses-shallot-rice). The type of soils in study sites were vertisol. The experimental field was conducted at Brebes regency, Central Java, Indonesia (Figure 1), that situated at latitude $109^{\circ} 3^{\prime} 24.7608^{\prime \prime} \mathrm{E}$ and longitude $6^{\circ} 51^{\prime}$ 59.0688"S for PP1, at latitude $109^{\circ} 2^{\prime} 40.4268^{\prime \prime} \mathrm{E}$ and longitude $6^{\circ} 53^{\prime} 13.2288^{\prime \prime} \mathrm{S}$ for PP2 and latitude $109^{\circ} 0^{\prime}$ 15.084"E and longitude $6^{\circ} 57^{\prime} 14.706^{\prime \prime S}$ for PP3.

\section{Soil properties analysis}

Soil samples were analyzed for physical and chemical properties including organic $\mathrm{C}$, total $\mathrm{P}_{2} \mathrm{O}_{5}$, total $\mathrm{S}$, and sulfate using the colorimetric method. Other soil properties such as total $\mathrm{N}$ (Kjeldahl method), $\mathrm{pH}$ (electrometric method), total $\mathrm{K}_{2} \mathrm{O}$ (Flame photometry method), bulk density (candle method), particle density (pycnometer method), cation exchange capacity (distillation method), organic matter (conversion method), $\mathrm{C} / \mathrm{N}$ ratio (calculation method) and porosity (calculation method) were also analyzed (Balittanah 2009).
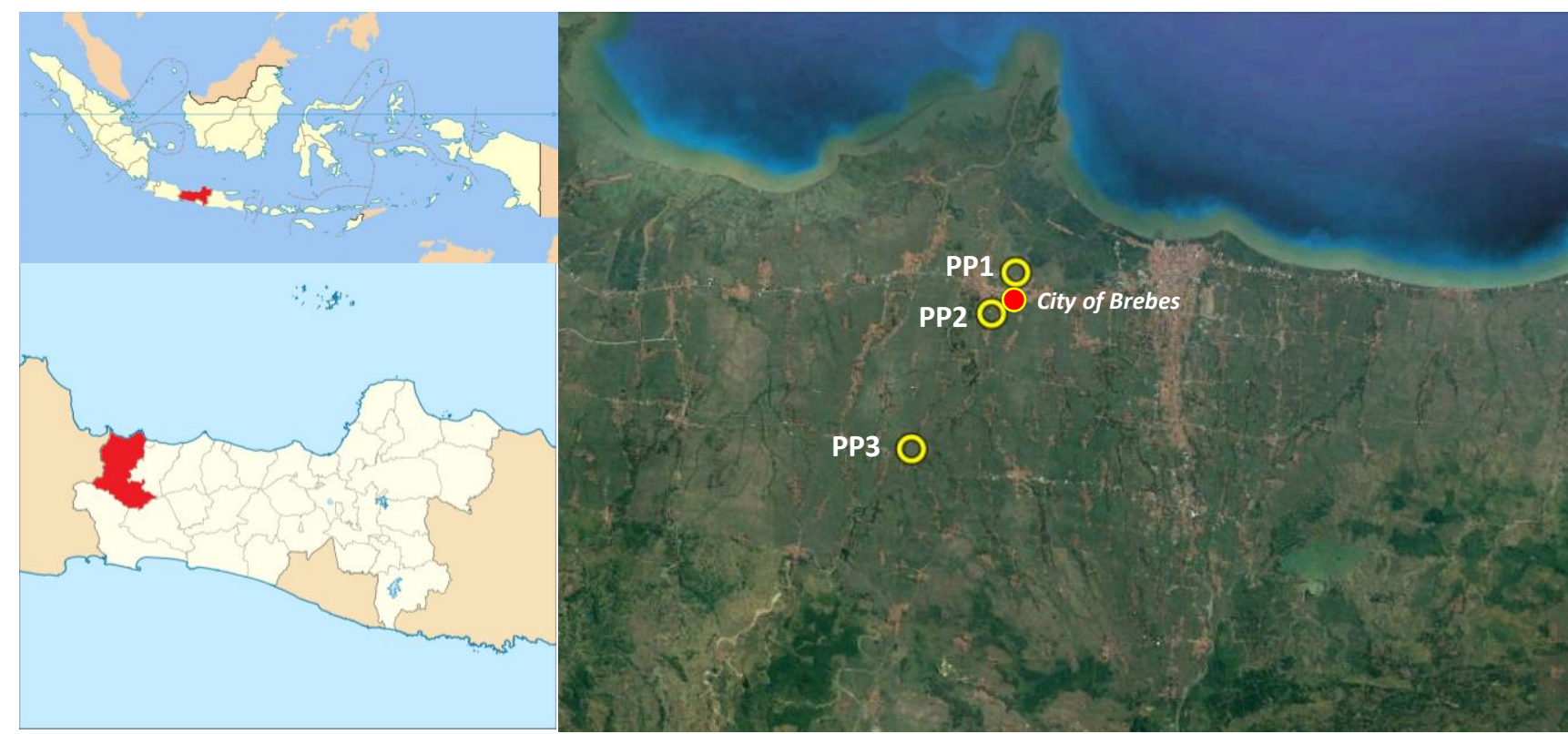

Figure 1. A map of Central Java province, Indonesia showing Brebes District as the study site 


\section{Isolation and identification of bacteria}

Bacterial samples were collected from rhizosphere soil. Starkey broth medium containing $3.0 \mathrm{~g} \mathrm{KH}_{2} \mathrm{PO}_{4}, 0.2 \mathrm{~g}$

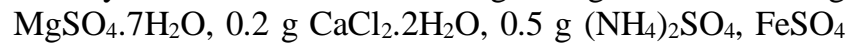
and $10 \mathrm{~g}$ sulfur powder in $1000 \mathrm{~mL}$ of distilled water was used for culturing bacteria (Vidyalakshmi and Sridar 2007). Bromocresol purple was used as an indicator. Twenty grams of soil samples from each planting pattern were added into $80 \mathrm{~mL}$ sterilized Starkey broth $(1: 4 ; \mathrm{pH} 4.8)$ and incubated $32^{\circ} \mathrm{C}$ for 24 hours, and Starkey broth without soil sample was used as the negative control. After incubation, broth media were diluted with aqua dest (dilution factor: $\left.10^{-1-} 10^{-7}\right)$. One hundred $\mu \mathrm{l}$ of each diluted solution $\left(10^{-3-} 10\right.$ $\left.{ }^{7}\right)$ were plated into Starkey agar media with three replications. The bacteria obtained were analyzed for their density using Total Plate Count (TPC) and then purified. The bacteria were stored in Starkey agar media and broth.

\section{S rRNA gene sequence analysis}

Phylogeny of the isolated bacterial strains was analyzed based on 16S rRNA gene sequences. General steps for $16 \mathrm{~S}$ rRNA gene sequence analysis included DNA extraction, amplification of $16 \mathrm{~S}$ rRNA gene sequences, purification of amplicons, and cycle sequencing. DNA extraction and PCR amplification were performed according to the manufacturer's protocol (KOD FX Neo, Toyobo). The genomic DNA isolated from SOB isolates were used to amplify the $16 \mathrm{~S}$ rRNA gene by PCR using universal primers F27 5'-AGAGTTTGATCCTGGCTCAG-3' and 1492R 5'-TACCTTGTTACGACTT-3' forward and reverse primer, respectively (Amutha and Kokila 2012). The amplified 16S rRNA gene products were sequenced, analyzed, and compared with $16 \mathrm{~S}$ rRNA gene sequences from the GeneBank database of NCBI (http://blast.ncbi.nlm.nih.gov/). Phylogenetic relationships of the isolated bacterial strains were determined using MEGA 7.0 software (Kumar et al. 2016).

\section{Data analysis}

Data obtained were analyzed using descriptive statistics.

\section{RESULTS AND DISCUSSION}

\section{Soil properties}

The physical and chemical properties of soil samples from three different planting patterns of shallot are shown in Table 1. The highest sulfate (41.31 ppm), organic C $(0.957 \%)$, organic matter $(1.650 \%)$ contents, $\mathrm{C} / \mathrm{N}$ ratio (9.57), and bulk density $\left(1.357 \mathrm{~g} / \mathrm{cm}^{3}\right)$ were obtained in the soils of PP3. Whereas, highest particle density $(2.495$ $\mathrm{g} / \mathrm{cm} 3$ ), cation exchange capacity (CEC) (41.913 me\%), and porosity $(46.012 \%)$ were observed in the soils of PP1. The results indicated that varying planting patterns affect soil properties.

\section{Identification of bacteria}

Three SOB isolates were successfully isolated from soil samples collected from different planting patterns of shallot (Figure 1). Isolate A-3245D was isolated from soil samples of PP3; isolate B-3246F was isolated from all planting patterns, and isolate C-3247 was isolated from soil samples of PP2 and PP3. The three isolates were identified as Burkholderia cepacia (isolate A-3245D), Klebsiella variicola (isolate B-3246F), and Klebsiella aerogenes (isolate C-3247C) (Table 2).

\section{Diversity of sulfur-oxidizing bacteria}

SOB diversity in different planting patterns of shallot is presented in Figure 2. K. variicola was identified as a bacterial species that were able to survive in the soil of three different planting patterns of shallot. The amplification of the 16S rRNA gene for all tested isolates produced fragments at $750 \mathrm{bp}(\mathrm{A}-3425 \mathrm{D}), 1000 \mathrm{bp}$ (B3246F), and 1500 bp (C-3247), respectively (Figure 3). Phylogenetic analysis showed three bacterial strains isolated i.e. A-3245D, B-3246F, and C-3247C were closely related to Burkholderia cepacia, Klebsiella variicola, and Klebsiella aerogenes, respectively (Figures 4-6).

Table 1. Physical and chemical properties of soil at three different planting patterns of shallot

\begin{tabular}{llll}
\hline Parameter & \multicolumn{3}{c}{ Planting pattern } \\
\cline { 2 - 4 } & PP1 & PP2 & PP3 \\
\hline Organic C & $0.859 \%$ & $0.886 \%$ & $0.957 \%$ \\
Total N & $0.132 \%$ & $0.101 \%$ & $0.100 \%$ \\
$\mathrm{C} / \mathrm{N}$ ratio & 6.51 & 8.77 & 9.57 \\
Organic matter & $1.481 \%$ & $1.528 \%$ & $1.650 \%$ \\
$\mathrm{pH} \mathrm{H}_{2} \mathrm{O}$ & 7.49 & 7.33 & 7.2 \\
Total $\mathrm{P}_{2} \mathrm{O} 5$ & $0.182 \%$ & $0.067 \%$ & $0.062 \%$ \\
Total $\mathrm{K}_{2} \mathrm{O}$ & $0.230 \%$ & $0.093 \%$ & $0.128 \%$ \\
Total S & $138.06 \mathrm{ppm}$ & $181.96 \mathrm{ppm}$ & $178.74 \mathrm{ppm}$ \\
Sulfate $\left(\mathrm{SO}_{4}\right)^{2-}$ & $15.67 \mathrm{ppm}$ & $4.79 \mathrm{ppm}$ & $41.31 \mathrm{ppm}$ \\
Bulk density & $1.347 \mathrm{~g} / \mathrm{cm}^{3}$ & $1.216 \mathrm{~g} / \mathrm{cm}^{3}$ & $1.357 \mathrm{~g} / \mathrm{cm}^{3}$ \\
Particle density & $2.495 \mathrm{~g} / \mathrm{cm}^{3}$ & $2.637 \mathrm{~g} / \mathrm{cm}^{3}$ & $2.555 \mathrm{~g} / \mathrm{cm}^{3}$ \\
Porosity & $46.012 \%$ & $53.887 \%$ & $46.888 \%$ \\
CEC & $41.913 \mathrm{me} \%$ & $50.586 \mathrm{me} \%$ & $43.089 \mathrm{me} \%$ \\
\hline
\end{tabular}

Note PP1 (Planting Pattern 1): shallot-dry season-shallot-shallot, PP2 (Planting Pattern 2): shallot-dry season-shallot-rice, and PP3 (Planting Pattern 3): shallot-pulses-shallot-rice, CEC: cation exchange capacity 


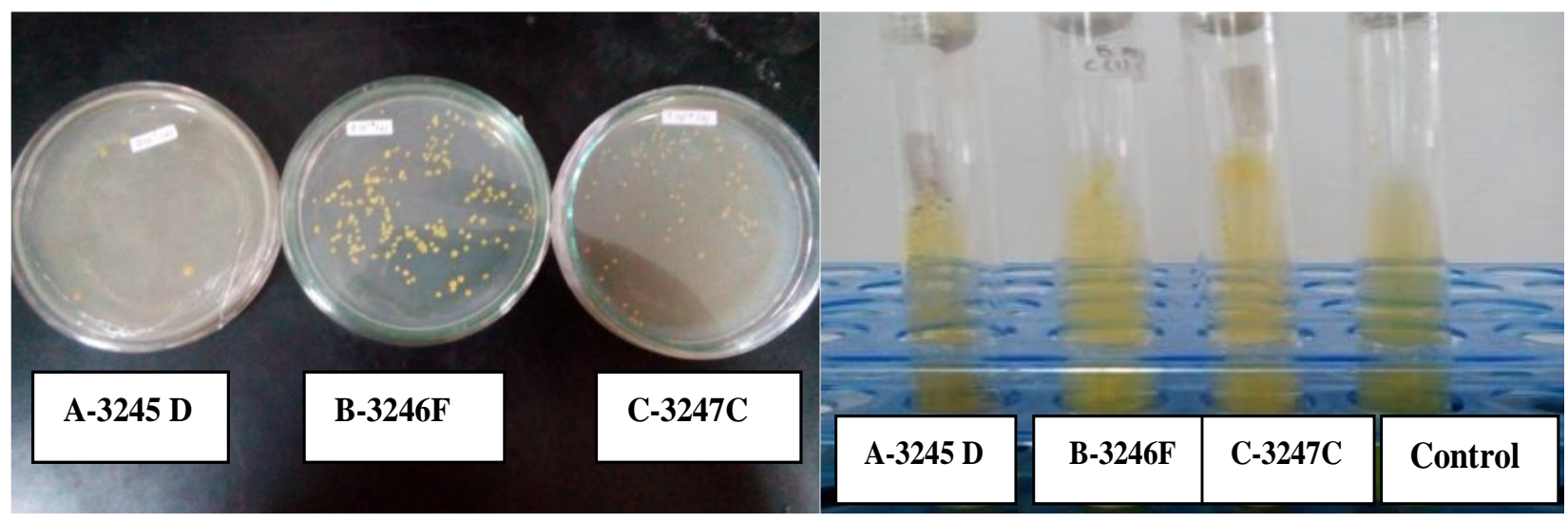

Figure 1. Sulfur-oxidizing bacteria (A-3245D, B-3246F and C-3247C) from soil samples of shallot rhizosphere

Table 2. Sulfur-oxidizing bacteria isolated from shallot rhizosphere

\begin{tabular}{llll}
\hline \multirow{2}{*}{ Isolate } & \multicolumn{3}{c}{ Bacterial isolate } \\
\cline { 2 - 4 } & \multicolumn{1}{c}{ PP1 } & \multicolumn{1}{c}{ PP2 } & PP3 \\
\hline A-3245D & - & - & Burkholderia cepacia \\
B-3246F & Klebsiella variicola & Klebsiella variicola & Klebsiella variicola \\
C-3247C & - & Klebsiella aerogenes & Klebsiella aerogenes \\
\hline
\end{tabular}

Note: PP1 (Planting Pattern 1): shallot-dry season-shallot-shallot, PP2 (Planting Pattern 2): shallot-dry season-shallot-rice, and PP3

(Planting Pattern 3): shallot-pulses-shallot-rice

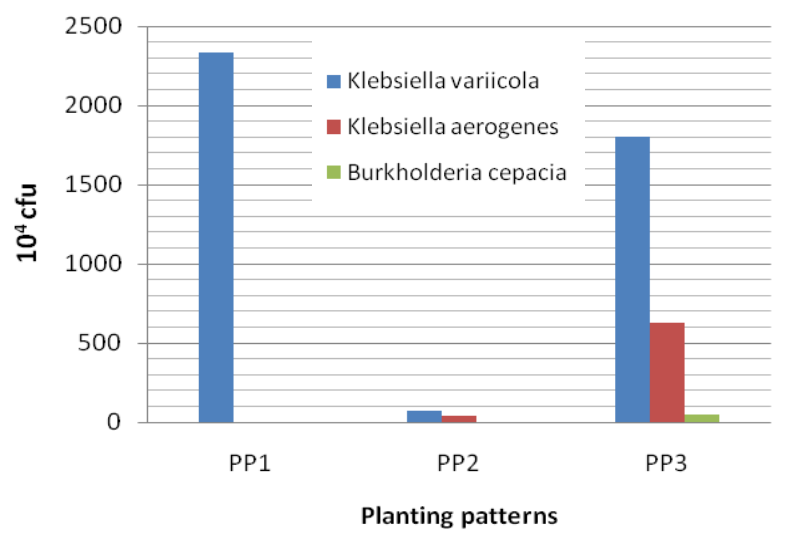

Figure 2. Diversity of Sulfur-oxidizing bacteria in three different planting patterns of shallot

\section{Discussion}

The growing bacteria change the color of the growth medium from greenish-yellow to brownish-yellow. The color change from greenish-yellow to brownish-yellow can be used as an indicator that SOB can grow well and signs of oxidation reaction that converts sulfur to sulfate (Puspitasari et al. 2014; Vidyalakshmi and Sridar 2007). The SOB had round, smooth, and yellow colonies (Figure $1)$.

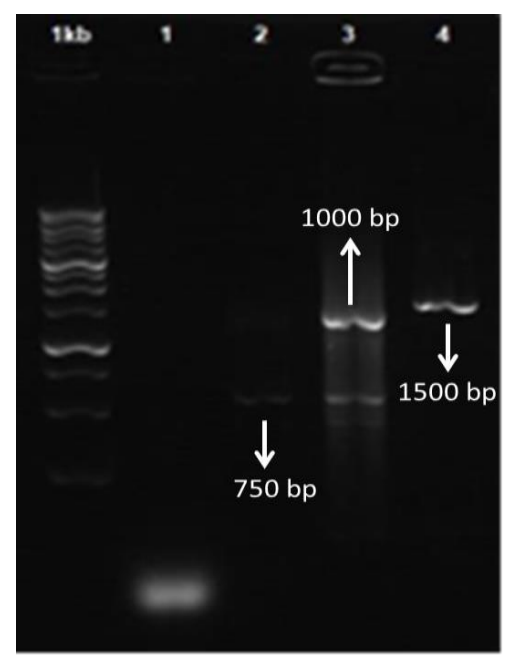

Figure 3. 16S rRNA gene amplification profile of SOB isolates. Lane 1kb: DNA marker, Lane 2: isolate A-3425D (750 bp), Lane 3: isolate B-3246F (1000 bp), Lane 4: C-3247C (1500 bp)

Soil samples in PP1 have the lowest total S, organic C, and organic matter contents. It might be associated with continuous shallot cultivation throughout the year so that the return of organic material was lower than organic matter from plant residues. After harvesting, the straw and pulses residues are left on the field to decompose and used by plants as sources of organic matter. The long-term addition of crop straw on soil increases organic $\mathrm{C}$ content in the soil, which is a key determinant of soil fertility ( $\mathrm{Li}$ et al. 2015). 


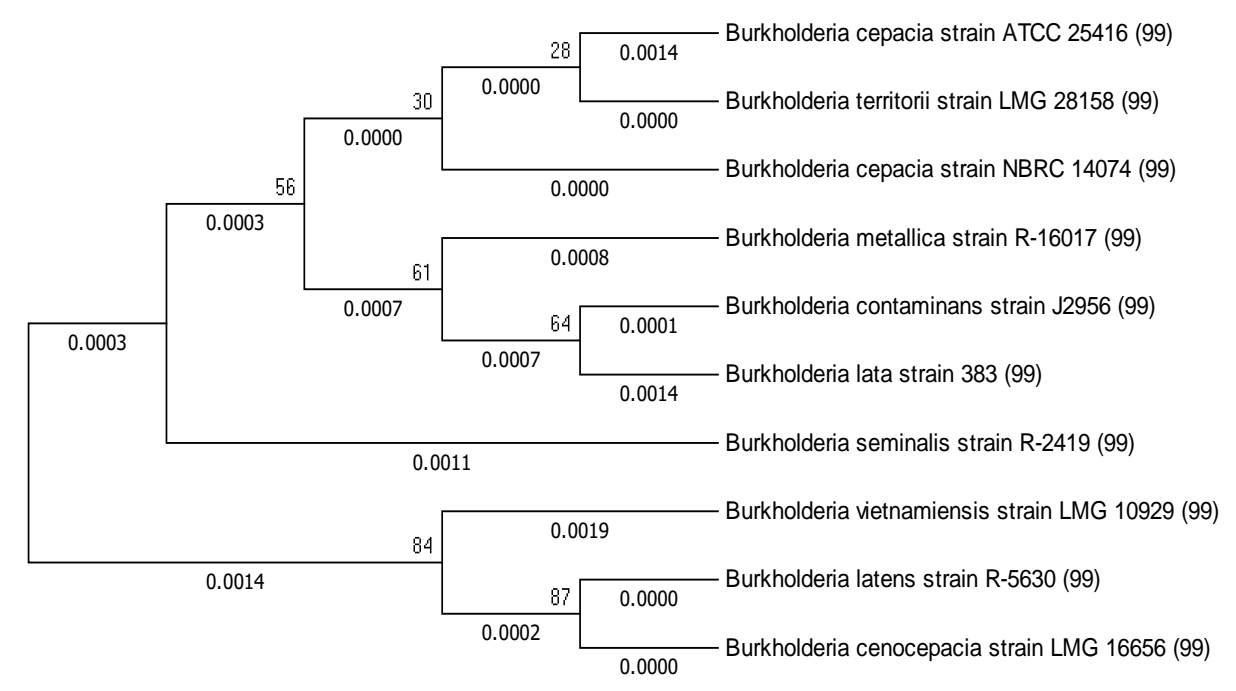

Figure 4. Phylogenetic tree of bacterial isolate A-3245D based on 16S rRNA gene identified as Burkholderia cepacia

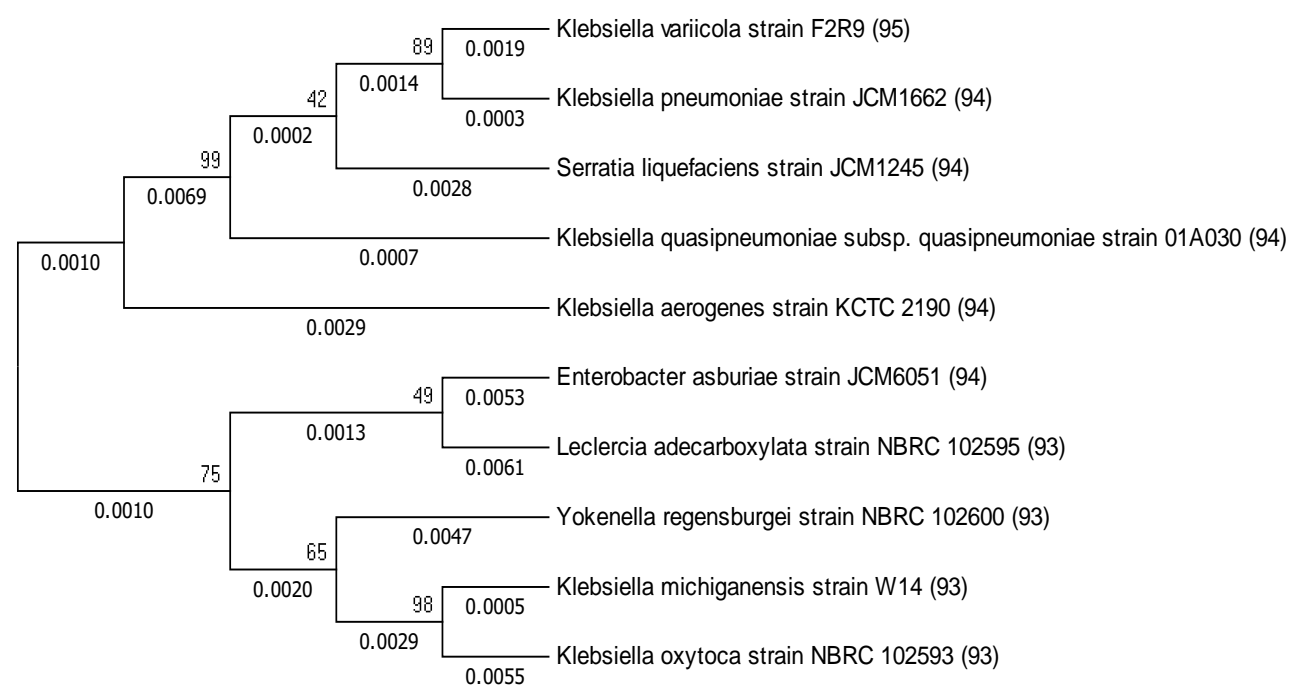

Figure 5. Phylogenetic tree of bacterial isolate B-3246F based on 16S rRNA gene identified as Klebsiella variicola

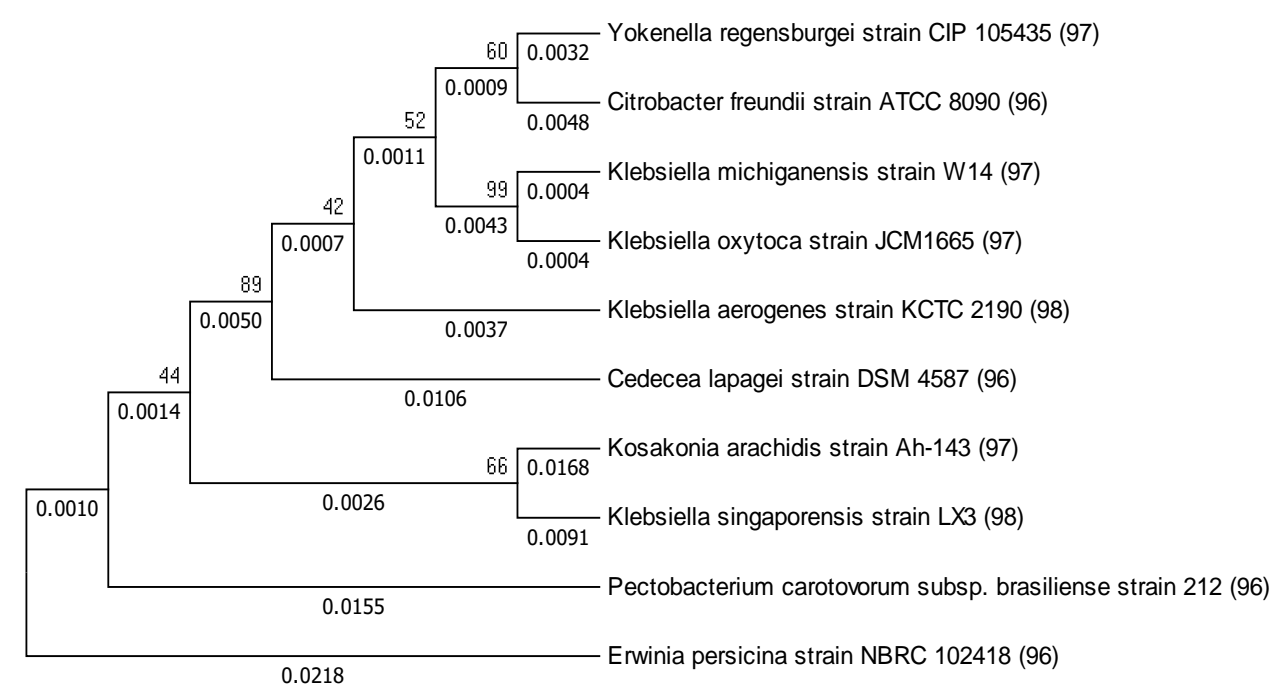

Figure 6. Phylogenetic tree of bacterial isolate C-3247C based on 16S rRNA gene identified as Klebsiella aerogenes 
According to Gaofei et al. (2010), the content of soil organic matter correlates with the organic carbon content in the soil, but increasing soil organic matter content results in a decrease soil $\mathrm{pH}$. The leaf straw of shallot has organic carbon content $(35.2 \%)$ which is lower than rice straw $(36.8 \%)$ and soybean straw (51\%) (Pandey et al. 2008). Congreves et al. (2017) reported that plant cultivation without a rotation system results in low soil organic carbon content. Liu et al. (2015) reported that planting similar plant species without crop rotation systems may have a negative effect called "secondary soil salinization" due to excessive use of chemical fertilizer which can also influence soil fertility.

It is known that sulfur is an essential nutrient for shallot growth. In PP1, shallot cultivation throughout the year results in a decrease of total sulfur in soil caused by high absorption of sulfur by plant roots. Soil samples in PP1 had the highest $\mathrm{pH}$ (7.49) and the lowest CEC (41.913 me\%) which may be due to low organic matter. Soil organic matter increases in line with increasing levels of organic $\mathrm{C}$, sulfur, $\mathrm{K}_{2} \mathrm{O}$, CEC, and porosity of the soil, but an increase in soil organic matter decreases soil $\mathrm{pH}$ (Lasmini et al. 2015).

Organic matter in the soil undergoes decomposition by soil microorganisms resulting in the formation of a more complex organic matter called humus or humic acid (Schaeffer et al., 2015). The availability of humus increases soil CEC and improves nutrients absorption by the plant roots. Therefore, lower organic $\mathrm{C}$ and organic matter contents in PP1 might result in lower CEC. Tambone et al. (2007) reported that the addition of organic matter to the soil can increase cation exchange capacity.

In the present study, three isolates, namely A-3425D, B-3246F, and C-3247C, were successfully isolated from rhizosphere soils from three different planting patterns (Table 2). The genomic DNA of these isolates was subjected to amplification of the 16S rRNA gene (Figure 3 ). As a result, the amplified fragments obtained from all tested isolates were at $750 \mathrm{bp}(\mathrm{A}-3425 \mathrm{D}), 1000 \mathrm{bp}$ (B$3246 \mathrm{~F})$, and $1500 \mathrm{bp}$ (C-3247), respectively. Gel electrophoresis showed that the primers used were successfully amplified 16S rRNA gene from the tested samples, although DNA quality varied (Figure 3). It was shown that some samples produced PCR product fragments with a smear on the gel as observed in isolate A3245D/Burkholderia cepacia. The smear of DNA along with the amplified product may be associated with the quality of DNA and possible contamination of the genomic DNA with other products such as protein. However, the PCR products of those samples still work and 16S rRNA sequences were successfully amplified. Based on the phylogenetic analysis, the isolate A-3425D was identified as Burkholderia cepacia (99\% homologous sequence and $100 \%$ query coverage) (Figure 4), the isolate B-3246F was identified as Klebsiella variicola (95\% homologous sequence $95 \%$ and $99 \%$ query coverage) (Figure 5), and the isolate C-3247C was identified as Klebsiella aerogenes (98\% homologous sequence and $99 \%$ query coverage) (Figure 6).
Ammonium sulfate $\left(\mathrm{NH}_{4}\right)_{2} \mathrm{SO}_{4}$ and sulfur powder are the most widely used chemical fertilizers by shallot farmers in Brebes Regency, with a dose of $120.77 \mathrm{~kg} \mathrm{~S} / \mathrm{ha}$ (Juwanda 2011) that results in a high level of total sulfur in the soil. Moreover, the presence of SOB such as $K$. aerogenes, $K$. variicola, and $B$. cepacia in rhizosphere soil of shallot can increase sulfate content in the soil. Therefore, SOB can be used as natural agents for reducing the use of chemical fertilizers.

Klebsiella $s p$. is a bacterial species that can oxidize sulfur to sulfate (Behera et al. 2014). Lin et al. (2015) reported that $K$. variicola has potential as a biofertilizer agent, while $K$. aerogenes can oxidize sulfur to sulfate. Sulfate in the soil is taken up by roots and used for plant growth and development (Mason and Kelly 1988). Adequate sulfur content in the soil affects the levels of $\mathrm{N}$, $\mathrm{P}$, and $\mathrm{K}$ taken up by plant roots (Pradhan et al. 2015). According to Behera et al. (2014), Klebsiella sp. has a better ability to oxidize sulfur to sulfate than Bacillus sp. and plays an important role in the degradation of chlorpyrifos pesticides. The presence of Klebsiella sp. is important in the cultivation of shallot with high use of pesticides (Farhan et al. 2013).

Burkholderia sp. is another bacterial species that can oxidize sulfur to sulfate (Sridar et al. 2015). Belonging to the genus Burkholderia, B. cepacia is very useful for bioremediation of endosulfan-contaminated soil (Kumar et al. 2008) and usually used as a bioinoculant in agriculture (Khambalkar and Sridar 2015). Klebsiella and Burkholderia can grow well at soil pH of 7 (Lin et al. 2015; Manogaran et al. 2018; Satapute and Kaliwal 2016), while maximum oxidation of sulfur to sulfate by Klebsiella sp. reaches on a medium with a $\mathrm{pH}$ of 7 (Behera et al. 2016). Based on the results of SOB isolation, it showed that the diversity and population density of bacteria in soil samples of PP3 were higher than those in PP1 and PP2, i.e. $K$. aerogenes $\left(3.9 \times 10^{6} \mathrm{CFU} / \mathrm{ml}\right), K$. variicola $\left(1.79 \times 10^{7}\right.$ $\mathrm{CFU} / \mathrm{ml})$ and B.cepacia $\left(7.45 \times 10^{5} \mathrm{CFU} / \mathrm{ml}\right)$. As a result, there is the possibility of higher sulfur oxidation to sulfate in PP3. Soil samples in PP3 had an average $\mathrm{pH}$ of 7.2, which approaches neutral $\mathrm{pH}$ (7) as optimal $\mathrm{pH}$ for bacterial growth, but this $\mathrm{pH}$ was lower than other groups (Table 1). Increasing the level of soil sulfate results in decrease soil $\mathrm{pH}$ (Gevenez de Souza et al. 2015). The adequate availability of sulfate in the soil can increase the yield and quality of shallot bulbs (Pradhan et al. 2015). Soil samples from PP2 had the lowest sulfate content (4.79 ppm) that might be associated with lower SOB diversity, consequently, there was lower oxidation of sulfur to sulfate (Table 1 and Figure 2). Another study by Pivovarova (2012) showed that increasing soil sulfate results in increasing $\mathrm{SOB}$ diversity and decreasing soil $\mathrm{pH}$.

The results of the study showed that soil samples in PP1 had the highest nitrogen content. It might due to the higher population density of $K$. variicola (Figure 2). K. variicola can bind nitrogen (Lin et al. 2015), as one of the primary macronutrients required by plants at high concentration. Nitrogen content in the soil affects the absorption of macro-and micro-nutrients (phosphorus, potassium, and sulfur) taken up by the root plants and a determinant for the 
production of shallot bulbs (Hilman et al. 2014). Soil samples from PP1 had the highest nitrogen content and soil $\mathrm{pH}$, but the lowest sulfate content (138.06 ppm).

In conclusion, soil properties and SOB diversity depend on the shallot planting patterns. It is recommended that shallots should use PP3 planting patterns to obtain the highest sulfate, organic matter contents, and SOB diversity (Burkholderia cepacia, Klebsiella variicola, and Klebsiella aerogenes) in the soil.

\section{ACKNOWLEDGEMENTS}

The authors thank the Ministry of Research, Technology, and Higher Education of Indonesia for providing financial support. The authors also thank the University of Jenderal Soedirman, Purwokerto, Banyumas, Indonesia for providing research facilities.

\section{REFERENCES}

Amutha K, Kokila V. 2014. PCR amplification, sequencing of 16S rRNA genes with universal primers and phylogenetic analysis of Pseudomonas aeruginosa. Intl J Sci Res 3: 257-261.

Assefa AG, Mesgina SH, Abrha YW. 2013. Response of onion (Allium cepa $L$.) growth and yield to different combinations of $\mathrm{N}, \mathrm{P}, \mathrm{S}, \mathrm{Zn}$ fertilizers and compost in northern Ethiopia. Intl J Sci Res 4: 985-989.

Balai Penelitian Tanah (Balittanah). 2009. Analisis Kimia Tanah, Tanaman, Air dan Pupuk. Departemen Pertanian, Bogor. [indonesian]

Behera BC, Patra M, Dutta SK, Thatoi HN. 2014. Isolation and characterization of Sulfur oxidizing bacteria from mangrove soil of Mahanadi river delta and their Sulfur oxidizing ability. J Appl Environ Microbiol 2: 1-5.

Behera BC, Singh SK, Patra M, Mishra RR, Sethi BK, Dutta SK, Thatoi HN. 2016. Partial purification and characterisation of sulfur oxidase from Micrococcus $\mathrm{sp}$. and Klebsiella sp. isolated from mangrove soils of Mahanadi River Delta, Odisha, India. Univers J Microbiol Res 4 : $66-78$.

Central Bureau of Statistics (BPS). 2018. Brebes Dalam Data 2017. Bureau of Statistics of Brebes regency. Indonesia. [Indonesian]

Congreves KA, Hooker DC, Hayes A, Verhallen EA, Van Eerd LL. 2017. Interaction of long-term nitrogen fertilizer application, crop rotation, and tillage system on soil carbon and nitrogen dynamics. Plant Soil 410 (1-2): 113-127.

Diriba-Shiferaw G, Nigussie-Dechassa R, Woldetsadik K, Tabor G, Sharma JJ. 2015. Effect of nitrogen, phosphorus, and sulfur fertilizers on growth yield, and economic returns of garlic (Allium sativum L.). Sci Technol Arts Res J 4: 10-22.

Fageria NK. 2009. The Use of Nutrients in Crop Plants. CRC Press, Boca Raton, FL.

Farhan M, Khan AU, Wahid A, Ali AS, Ahmad F. 2013. Potential of endogenous Klebsiella sp. for chlorpyrifos biodegradation. Pakistan J Sci 65 (1): 133-137.

Gaofei, Li Z, Fan F, Chu G, Hou Z, Liang Y. 2010. Soil biological activity and their seasonal variations in response to long-term application of organic and inorganic fertilizers. Plant Soil 326: 31-44.

Gevenez de Souza LF, Filho ABC, Alberto de Túlio1 F, Nowaki RHD. 2015. Effect of sulfur dose on the productivity and quality of onions. Aust J Crop Sci 9 (8): 728-733.

Glab T, Cigalaska BS, Labuz B. 2013. Effect of crop rotation on the root system morphology and productivity of triticale $(\times$ Triticosecale Wittm). J Agric Sci 152: 642-654.

Hao DM, Dat NT, Tuyet DTA, Hiep LM, Binh HT, Kongmany P, Hiep HP, Huyen LT. 2019. Isolation and identification of some heterotrophic sulfur oxidizing bacteria is isolated in mangrove along to Haiphong-Quangninh coastal. Biol Forum Intl J 11: 117-123.

Hartini E. 2011. Kadar Plumbum $(\mathrm{Pb})$ dalam umbi bawang merah di Kecamatan Kersana Kabupaten Brebes. VISIKES: Jurnal Kesehatan Masyarakat 10 (1): 69-75. [Indonesian]
Hilman Y, Sopha, Lukman L. 2014. Nitrogen effect on production, nutrients uptake and nitrogen-use efficiency of shallot (Allium cepa var aggregatum). AAB Bioflux 6 (2): 128-133.

Jaggi RC, Sharma RK. 2010. Sulphur management in onion (Allium cepa) cultivation in hills of Himachal Pradesh. J Environ Biol 31 (3): 391-3

Juwanda M. 2011. Growth, Results and Efficiency Nitrogen of Fertilization to Shallot in Giving Doses of Nitrogen Fertilizer and Cow Manure. [Thesis]. Pascasarjana Program, University of Jenderal Soedirman, Banyumas. [Indonesian].

Khambalkar P, Sridar R. 2015. Isolation and characterization of nitrogen fixing Burkholderia sp. Intl J Agric Environ Biotechnol 8 (3): 681689.

Kumar M, Lakshmi CV, Khanna S. 2008. Microbial biodiversity and in situ bioremediation of endosulfan contaminated soil. Indian $\mathrm{J}$ Microbiol 48 (1): 128-133.

Kumar S, Stecher G, Tamura K. 2016. MEGA7: Molecular evolutionary genetic analysis version 7.0 for bigger datasets. Mol Biol Evol 33: 1870-1874.

Lasmini SA, Kusuma Z, Santoso M, Abadi AL. 2015. Application of organic and inorganic fertilizer improving the quantity and quality of shallot yield on dry land. Intl J Sci Technol Res 4 (4): 243-246.

Li Z, Zhao B, Wang Q, Cao X, Zhang J. 2015. Differences in chemical composition of soil organic carbon resulting from long-term fertilization strategies. PloS One 10 (4): e0124359. DOI: 10.1371/journal.pone.0124359.

Lin L, Wei C, Chen M, Wang H, Li Y, Li Y, An Q. 2015. Complete genome sequence of endophytic nitrogen-fixing Klebsiella variicola strain DX120E. Stand Genomic Sci 10 (1): 2-7.

Liu Y, Qian C, Daulet SM. 2015. Effect of dongshengbao liquid organic fertilizer on soil improvement of continuous cropping cucumber. Agric Sci Technol 16 (10): 2252-2255.

Losák T, Hlušek J, Kráěmar S, Varga L. 2008. The effect of nitrogen and sulfur fertilization on yield and quality of kohlrabi (Brassica oleracea, L.). Rev Bras Cienc Solo 32 (2) : 697-703.

Manogaran M, Ahmad SA, Yasid NA, Yakasai HM, Shukor MY. 2018. Characterisation of the simultaneous molybdenum reduction and glyphosate degradation by Burkholderia vietnamiensis AQ5-12 and Burkholderia sp. AQ5-13. 3 Biotech 8 (2): 117.

Mason J, Kelly DP. 1988. Thiosulphate oxidation by obligately heterotrophic bacteria. Microb Ecol 15 (2): 123-134.

Mohamed AA, Eweda WEE, Heggo AM, Hassan EA. 2014. Effect of dual inoculation with arbuscular mycorrhizal fungi and sulphur-oxidising bacteria on onion (Allium cepa, L) and maize (Zea mays, L) grown in sandy soil under green house conditions. Ann Agric Sci 59: 109-118.

Moradi Y, Moradi-Sardareh H, Ghasemi H, Mohamadi N, Moradi MN, Hosseini-Zijoud SM. 2013. Medicinal properties of Persian shallot. Eur J Exp Biol 3 (1): 371-379.

Pandey AK, Gaind S, Ali A, Nain L. 2009. Effect of bioaugmentation and nitrogen supplementation on composting of paddy straw. Biodegradation 20 (3): 293-306.

Pivovarova TA, Bulaev AG, Roshchupko PV, Belyi AV, Kondrat'eva TF. 2012. Oxidation of sulfur-containing substrates by aboriginal and experimentally designed microbial communities. Prikl Biokhim Mikrobiol 48 (6): 640-5.

Pourbabaee AA, Dinekaboodi SK, Hosseini HMS, Alikhani HA, Emami S. 2020. Potential application of selected sulfur-oxidizing bacteria and different sources of sulfur in plant growth promotion under different moisture conditions. Commun Soil Sci Plan 51 (6): 1-11.

Pradhan R, Pattnaik AK, Tripathy P, Mallikarjunarao K, Sahoo BB, Lenka J. 2015. Influence of sulfur fertilization on nutrient uptake of onion (Allium cepa L.). J Crop Weed 11: 134-138.

Prenafeta-Boldú FX, Rojo N, Gallastegui G, Guivernau M, Viñas M, Elías A. 2014. Role of Thiobacillus thioparus in the biodegradation of carbon disulphide in a biofilter packed with a recycled organic pelletized material. Biodegradation 25 (4): 557-568.

Puspitasari DH, Pramono, Oedjiono. 2014. Identifikasi bakteri pengoksidasi besi dan sulfur berdasarkan gen 16S rRNA dari lahan tambang timah di Belitung. Scripta Biologica 1 (1) : 8-14.

Riedell WE, Pikul JL, Jaradat AA, Shumacher TE. 2009. Crop rotation and nitrogen input effects on soil fertility, maize mineral nutrition, yield, and seed composition. Agron J 101 (4): 870-879.

Ryu HW, Moon HS, Lee EY, Cho KS, Choi H, 2003. Leaching characteristics of heavy metals from sewage sludge by Acidithiobacillus thiooxidans MET. J Environ Qual 32 (3): 751-759. 
Sabagh H, Khoramivafa M, Honarmand S, Al Agha AB. 2014. Effect of Thiobacillus bacteria, sulfur and manure on the nutrient and $\mathrm{pH}$ of soil in garlic (Allium sativum). Intl J Biosci 5 (4): 186-193.

Satapute P, Kaliwal B. 2016. Biodegradation of propiconazole by newly isolated Burkholderia sp. strain BBK_9. 3 Biotech 6 (1):110.

Schaeffer A, Nannipieri P, Kästner M, Schmidt B, Botterweck J. 2015. From humic substances to soil organic matter-microbial contributions In honour of Konrad Haider and James P. Martin for their outstanding research contribution to soil science. J Soil Sediment 15 (9): 1865 1881.

Sinha M, Atya K, Hemant J, Purohit. 2008. Study of biodiversity of Klebsiella sp. World J Microbiol Biotechnol 24: 203-207.

Sridar R, Veerender K, Sivaji M, Gayathri R. 2015. Genetic diversity of sulphur oxidizing bacteria from different ecosystems. Indian $\mathrm{J}$ Biotechnol 14: 72-80.

Sriramachandrasekharan MV. 2012. Sulfur use efficiency of radish as affected by sulfur source and rate in typic ustifluvent soil. Commun Biometry Crop Sci 7 (1): 35-40.
Sulasih, Widawati S. 2019. The application of Klebsiella sp. and Rhizobium radiobacter as biofertilizer and Palm Oil Mills Effluent (POME) as organic fertilizer on growth of Paraserianthes falcataria. IOP Conf Ser Earth Environ Sci 308: 012057. DOI: 10.1088/17551315/308/1/012057.

Tambone F, Genevini P, Adani F. 2007. The effect of short-term compost application on soil chemical properties and on nutritional status of maize plant. Compost Sci Util 15 (3): 176-183.

Ullah I, Jilani G, Khan KS, Akhtar MS, Rasheed M. 2014. Sulfur oxidizing bacteria from sulfur rich ecologies exhibit high capability of phosphorous solubilization. Intl J Agric Biol 16 (3): 550-556.

Velivelli SL, Sessitsch A, Prestwich BD. 2014. The role of microbial inoculants in integrated crop management systems. Potato Res 57 (34): 291-309.

Vidyalakshmi R, Sridar R. 2007. Isolation and characterization of sulfur oxidizing bacteria. J Culture Collect 5 (1): 73-77. 